Hülya ARSLAN ${ }^{1}$

Sait ENGINDENIZ2

Gökhan ÇINAR ${ }^{3}$

1 TC Orman Genel Müdürlüğü, İzmir Orman Bölge Müdürlüğü, 35530 İzmir / Türkiye

2 Ege Üniversitesi, Ziraat Fakültesi, Tarım Ekonomisi Bölümü, 35100 İzmir / Türkiye

${ }^{3}$ Adnan Menderes Üniversitesi, Ziraat Fakültesi, Tarım Ekonomisi Bölümü, 09970 Aydın / Türkiye sorumlu yazar: hulya.kafadar@hotmail.com

Anahtar Sözcükler:

Odun dışı bitkisel orman ürünleri, tüketici davranışları, tüketici analizi, tüketim eğilimi

Key Words:

Non-wood forest products, consumer behaviors, consumer analysis, consumption trends

\section{İzmir İli Kentsel Kesiminde Odun Dışı Bitkisel Orman Ürünleri Tüketiminin Analizi Üzerine Bir Araştırma*}

\author{
A Research on Analysis of Non-Wood Forest Products \\ Consumption in Urban Area of Izmir \\ * illk yazarın yüksek lisans tezinden alınmıştır. \\ Alınış (Received): 26.02.2016 Kabul tarihi (Accepted): 08.04.2016
}

ÖZET

Qu araştırmanın temel amacı, İzmir ili kentsel kesiminde odun dışı bitkisel Dorman ürünlerine (ODBÜ) ilişkin hane halkları ile yapılan anketlerden elde edilen veriler doğrultusunda, tüketim yapısını, tüketici eğilimlerini ve tercihlerini analiz etmektir. Bu amaca yönelik olarak Karşıyaka ilçe merkezinde 96 hane halkı ile anket yapılmıştır. Araştırma sonucunda görüşülen hane halklarının büyük bir bölümü bu ürünleri ODBÜ adı altında tanımamaktadır. Kendi doğal ortamında katkı maddesi içermeden elde edilmesi, lezzetli ve aromatik gıdalar olmaları ve koruyucu, bağışıklık sistemini güçlendirici özelliklerinden dolayı tercih edilen ürünlerdir. Tüketicilerin tercih ettiği çeşit, miktar ve şekilde ürün üretimi ile tüketici kitlesinin doğru belirlenmesi sonucunda, üretimden pazarlamaya kadar olan sürecin etkin çalışması ve sürdürülebilirliği sağlanabilecektir.

\section{Gíkiş}

Orman kaynakları içinde odun üretimi önemli bir yer tutmakla birlikte, toplumun ormanlara yönelik değişen ve artan talepleri ormanların odun üretimi dışındaki işlevlerinin önemini de giderek artırmaktadır. Tali ürün veya yan ürün olarak ifade edilen odun dışı orman ürünleri (ODOÜ), çeşitli orman kaynaklarından elde edilen odun dışındaki ürünlerin tümünü içermektedir.
ODOÜ, ormanlar ve ormanlara bitişik arazilerden elde edilen odun dışındaki biyolojik kökenli ürünler (bitkisel ve hayvansal kökenli ürünler) ve hizmetlerden (rekreasyon, hayvan otlatma, $\mathrm{CO}_{2}$ tutma, oksijen oluşturma, gen kaynağı sağlama, bilimsel amaçlı yararlanma, su rezervi ve erozyon kontrolü vb.) oluşmakta ve ODOÜ bünyesinde; odun dışı bitkisel ürünler, hayvansal ürünler ve ormanların sunduğu çeşitli hizmet ve fonksiyonlar şeklinde üçlü bir ayırım 
söz konusu olabilmektedir (Prasad, 1999; Özuğurlu ve Düzgün, 2000). ODOÜ, orman alanlarında, orman içi açıklıklarda doğal olarak yetişen bitkilerden elde edilen uçucu yağlar ve diğer kimyasal maddeler, ilaç, kozmetik, boya, deri, gıda, şekerleme ve alkollü içki üretimi gibi birçok sanayi kolunda geniş kullanım alanı bulmaktadır. Son yıllarda ODOÜ'ne yönelik bilinçlenme ve talep gittikçe artmaktadır. Bu artışta, yerel ve ulusal ekonomiler açısından ODOÜ'nin önemli bir gelir ve istihdam kaynağı olarak görülmeye başlamasının ve dünyada genel olarak doğal ve kaliteli ürünlere olan talep artışının da payı bulunmaktadır (Türker ve ark., 2006; Özden and Dios-Palomares, 2015; Özden, 2016).

Özellikle odun dışı bitkisel orman ürünlerine (ODBÜ) verilen önemin artışına paralel olarak bu konularda yapılan çalışmalar da artmıştır. Örneğin Türkiye'de, ODBÜ üretim tekniği, kullanım yeri, inracatı, talep durumu, ekonomiye katkıları gibi konularda çalışmalar yapıldığı görülmektedir (Bilgin, 1996; Karayılmazlar ve Yazıcl, 2002; Özkan ve ark., 2002; Artukoğlu et al., 2002; Artukoğlu ve Uzmay, 2003; Özgüven ve ark., 2005; Bayram ve ark., 2010; Faydaoğlu ve Sürücüoğlu, 2011; Arslan ve ark., 2015). Bunun yanında, ODBÜ işletmeciliğini değişik açılardan (yasal, kurumsal vb.) irdeyen ve tedarikten pazarlamaya kadar geçen süreçte karşılaşılan sorunlar belirleyerek çözüm önerileri geliştiren çalışmalar da yapılmıştır (Türker ve ark., 2001; 2002).

Günümüzde tüketicilerin katkı maddesi içermeyen kendi doğal ortamında (orman içi ve açıklarında) toplanan ODBÜ'ne yönelik ilgisinin artması, bu ürünlere karşı talep artışını da beraberinde getirmektedir. Ayrıca, bu ürünlerin koruyucu olarak sağlık ve bağışıklık sistemini güçlendirmeye yardımcı olması, hastalıkları önlemede ve hastalık sonrası bilimsel tıbba destek olması nedeniyle de son yıllarda kullanımı daha yaygın hale gelmiştir. Ancak bugüne kadar ODBÜ ile ilgili tüketim düzeyi, tüketici davranış ve tutumlarına yönelik yapılan çalışma sayısı ise oldukça sınırlıdır (Korkmaz ve Fakir, 2009; Dicle, 2010). ODBÜ'e yönelik hem kırsal kesimde, hem de kentsel alanlarda tüketim durumu hakkında mevcut veriler yetersiz olup, güvenilir de değildir. Bu bağlamda; ODBÜ'den faydalanılmasına yönelik tüketici tutum ve davranışlarının belirlenmesi ile ilgili araşsırmalara öncelik verilmesinin gerekliliği ortaya çıkmaktadır.

Bu çalışmada, İzmir ilinin Karşıyaka ilçe merkezinde yaşayan hane halklarının ODBÜ'e yönelik tüketim yapısı incelenmiş ve bu yöndeki tutum ve davranışları analiz edilmiştir.

\section{MATERYAL ve YÖNTEM}

\section{Materyal}

Araştırma kapsamına bu bölgede daha önce konuyla ilgili benzer bir çalışma yapılmadığı için İzmir'in Karşıyaka ilçesi alınmıştır. Dolayısıyla araştırmanın ana materyalini İzmir'in Karşıyaka ilçe merkezindeki hane halkları ile yüz yüze yapılan anket çalışmasından elde edilen veriler oluşturmaktadır. Ayrıca konu ile ilgili olarak yurtiçi ve yurtdışında daha önce hazırlanmış araştırma, makale, bildiri, inceleme, tezlerden ve konu ile ilgili kurumların yayınladığı istatistiksel verilerden de yararlanmıştır.

\section{Yöntem}

\section{Verilerin toplanmasında kullanılan yöntemler}

İzmir'in Karşıyaka ilçesindeki toplam hane halkı sayısı çalışmanın ana kitlesini oluşturmaktadır. 2013 yılı Adrese Dayalı Nüfus Sayımı verilerine göre Karşıyaka ilçesinde toplam 117.901 hane halkı bulunmaktadır. Araştırma kapsamına alınacak hane halkı sayısını belirlemek üzere aşağıdaki oransal örnekleme formülünden yararlanılmıştır (Newbold, 1995).

$$
n=\frac{N p(1-p)}{(N-1) \sigma_{P}^{2}+p(1-p)}
$$

Formülde;

$\mathbf{n}=$ Örnek hacmi

$\mathbf{N}=$ Toplam hane halkı sayısı

$\mathbf{p}=$ ODBÜ tüketen hane halkı oranı (maksimum örnek hacmine ulaşmak için 0.50 alınmıştır)

$\boldsymbol{\sigma}_{\mathbf{p}}^{2}=$ Varyansdır.

Yukarıdaki formülden yararlanılarak \%95 güven aralığı ve \%10 hata payı esas alınarak kapsama alınacak hane halkı sayısı 96 olarak hesaplanmıştır. Hane halkı belirlenmesinde her mahallede 6 sokakta anket yapılarak Karşıyaka IIlçe genelinde bulunan 27 mahalleden 16'sı mahalle listesinden rassal olarak belirlenmiştir. Araştırma anketleri sırasında tüketicilere önce ODBÜ konusunda bilgilerinin olup olmadığı sorulmuş, daha sonra bu ürünlerin çeşitliliği ve kapsamı hakkında kendilerine genel bilgiler verilmiştir.

\section{Verilerin analizinde kullanılan yöntemler}

Araştırma verilerinin Excel programında girişi yapılmış, daha sonra elde edilen sonuçlar çizelgeler olarak düzenlenmiş ve yüzde dağılımları ile yorumlanmıştır. Araştırmada önce hane halklarının demografik yapısı ortaya konulmuştur. Daha sonra ODBÜ yönelik bilgi düzeyleri, bilgi kaynakları, satın alma ve tüketim amaçları, satın alma yerleri, satın alma ve tüketim şekilleri analiz edilmiştir. Ayrıca bu ürünlerin 
tüketiminde önem verilen kriterler ve tercihler ekonometrik olarak da incelenmiştir.

Araştırmada hane halkının ODBÜ tüketmede öncelik verdiği kriterleri ortaya koymak amacıyla Bulanık Eşli Karşılaştırma (BEK) yönteminden yararlanılmıştır. Bu yöntem, basit eşli karşılaştırma yöntemiyle benzerlik göstermektedir ve her ikisinde de tüketiciler iki amacı karşılaştırmaktadır. Diğer taraftan bu yöntemde, bir amacın diğerine göre tercih derecesi ortaya konulmakta ve ayrıca tüketicilerin iki amaç arasında kayıtsız kalmaları sağlanmaktadır. Ayrıca yöntemde her kriterin sayısal değeri, karşılaştııılan kriterler kümesine dayalıdır (Bektaş ve ark., 2009).

$\mathrm{Bu}$ yöntemde ayrıca sayısal büyüklük tahmin yönteminden farklı olarak, her amacın sayısal değeri karşılaştırılan amaçlar kümesine dayalıdır. Kısmi üyelik, bulanık küme teorisinin merkezi bir kavramıdır. Klasik üyelik teorisinde bir küme, evrensel kümenin her bir elemanı söz konusu kümenin elemanı olması (yani 1) veya olmaması (yani 0)durumu ortaya konulduğunda iyi tanımlanmış olarak kabul edilmektedir. Kısmi üyelikte ise, bulanık küme $[0,1]$ kapalı aralığında yer almaktadır. Bu yüzden kümenin bir elemanına 0 ve 1 arasında bi $r$ değer verilmektedir. Bulanık küme teorisi belirsiz tercihlere dayanmaktadır. Bulanık kümeler, keskin olmayan sınırlara sahip bir sınıflandırmadır (Tanaka, 1997). Bulanık kümeler kavramında 0 ile 1 arasında değişen üyelik derecelerinden de söz etmek mümkündür. Üyelik derecesi klasik kümelerde, kümeye ait olup olmama durumunu gösterirken, bulanık kümelerde ise 0 ile 1 arasındaki değişimin herbir eleman için değerini ifade etmektedir (Klir and Yuan, 1995; Pedrycz and Gomide, 1998). Yöntemde birinci aşama, veri toplamadır. Veri toplama aşamasında aşağıdaki diyagram kullanılmaktadır (Şekil 1).

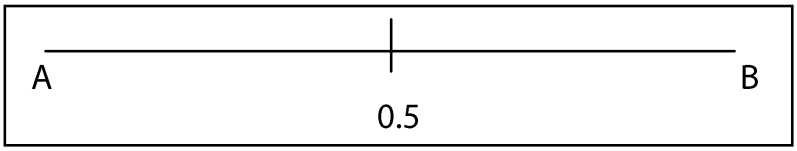

Şekil 1. A ve B arasında karşılaştırma yapmak amacıyla kullanılan bulanık eşleme yaklaşımı

Figure 1. A fuzzy matching approach used for making comparisons between $A$ and $B$

A ve $B$ amaçları, çizginin zıt taraftaki uçlarına yerleştirilmektedir. tüketicilerden tercihini belirtmek üzere çizginin üzerine $X$ işareti koyması istenmektedir. Amaçlar karşılaştırılırken; hangi amaç $X$ işaretine daha yakın mesafede ise, onun diğerine tercih edildiği söylenebilir. B'ye göre $A^{\prime} n ı n$ tercih derecesi, RAB, X işaretinden $A^{\prime}$ ya olan uzaklıkla ölçülmektedir. $A^{\prime}$ dan B'ye toplam uzaklık 1'dir.
Eğer $R A B<0,5$ ise $B>A$

Eğer $R A B=0,5$ ise $A \approx B$

Eğer $R A B>0,5$ ise $A>B$

Kesin tercihler olması durumunda $R A B=1$ veya $R A B=0$ Amaçlara ait eşli karşılaştırmaların sayısı, $K$, aşağıdaki gibi belirlenmektedir;

$$
\mathrm{K}=\mathrm{n} *(\mathrm{n}-1) / 2
$$

Burada n, amaçların sayısını ifade etmektedir. Her bir

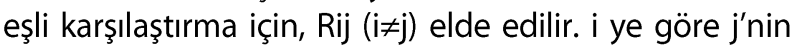
tercih derecesinin ölçümü de: Rji=1-Rij şeklinde olacaktır.

İkinci aşama, bulanık tercih matrisinin oluşturulmasıdır. Veriler toplanıp, yukarıda anlatılanlar doğrultusunda işlendikten sonra tüketicilerin bulanık tercih matrisi oluşturulabilmektedir. Bunun için aşağıdaki ifadeden yararlanılmaktadır (Günden and Thomas, 2012);

$$
R=\left(\begin{array}{c}
0 \text { eğer } i=j \forall i, j=1, \ldots \ldots \ldots, n \\
r_{i j} \text { eğer } i \neq j \forall i, j=1, \ldots \ldots \ldots, n
\end{array}\right)
$$

Yöntem ixj boyutlu bulanık tercih matrisi (R) ile açıklanabilir.

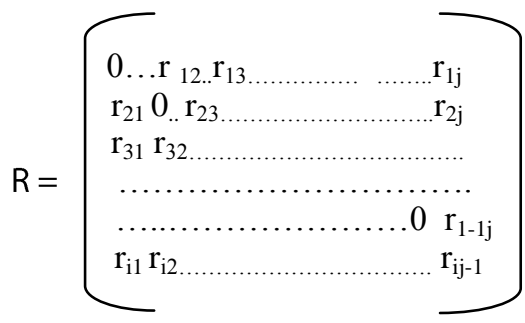

Yöntemin üçüncü aşaması, bulanık ağırlıkların ölçülmesidir. Tüketicinin tercih matrisinden her amaca ait tercihin ölçüsünü (i) hesaplamak mümkündür. Aşağıdaki formül her amacın ayrı ayrı tercih yoğunluğunu ölçmede kullanılmaktadır.

$$
\mathrm{Ij}=1-\left(\begin{array}{l}
\mathrm{n} \\
\sum R_{i j}^{2} /(n-l)
\end{array}\right)^{1 / 2}
$$

Son aşama ise amaçların sıralanmasıdır. lj değerleri 0 ile 1 arasında değişmektedir. Değer 1'e ne kadar yakınsa, söz konusu amacın tercih yoğunluğu o kadar büyük olmaktadır. lj'ler elde edildikten sonra amaçlar en önemliden en az önemliye doğru sıralanmaktadır (Günden ve Miran, 2007).

\section{ARAŞTIRMA BULGULARI}

\section{Demografik özellikler}

Araştırma kapsamına alınan hane halklarının demografik özelliklerine ilişkin bulgular Çizelge 1'de 
verilmiştir. Ankete katılan hane halkı üyelerinin \%46.88'ini erkekler, \%53.12'sini kadınlar oluşturmaktadır. Hane halkı üyelerinin \%80.21'i 30 yaşın, \% 57.29'u 40 yaşın üzerindedir. Ortalama yaş 42.52 olarak hesaplanmıştır. Hane halkı üyelerinin \%44.79'u üniversite mezunu ve \%70.83'ü çalışan kişilerdir. \%56.25'i evlidir. En fazla yaşadıkları yer Büyükşehir ve İ merkezidir. Hane halkında ortalama birey sayısı 3.07 olarak belirlenmiştir. Hane halkı bireylerinin \%81.35'i 15 yaş ve üzerindedir. Hane halklarının \%89.58'inin aylık geliri $3000 \mathrm{TL}$ ve üzerindedir.

Çizelge 1. Hane halklarının demografik özellikler

Table 1. The demographic characteristics of the households

\begin{tabular}{|c|c|c|c|}
\hline \multicolumn{2}{|l|}{ Demografik özellikler } & Sayı & $\%$ \\
\hline \multirow[t]{2}{*}{ Cinsiyet } & Erkek & 45 & 46.88 \\
\hline & Kadın & 51 & 53.12 \\
\hline \multirow{4}{*}{ Yaş } & $18-29$ & 19 & 19.79 \\
\hline & $30-41$ & 22 & 22.92 \\
\hline & $41-52$ & 38 & 39.58 \\
\hline & 53 ve üzeri & 17 & 17.71 \\
\hline \multirow{4}{*}{ Eğitim düzeyi } & İlkokul & 12 & 12.50 \\
\hline & Ortaokul & 14 & 14.58 \\
\hline & Lise & 27 & 28.13 \\
\hline & Üniversite & 43 & 44.79 \\
\hline \multirow{4}{*}{ Medeni durum } & Bekar & 28 & 29.17 \\
\hline & Evli & 54 & 56.25 \\
\hline & Eşi vefat etmiş & 8 & 8.33 \\
\hline & Eşinden ayrılmış & 6 & 6.25 \\
\hline \multirow{2}{*}{ Çalışma durumu } & Çalışıyor & 68 & 70.83 \\
\hline & Çalışmıyor & 28 & 29.17 \\
\hline \multirow{4}{*}{ En fazla yaşanılan yer } & Büyükşehir & 49 & 51.04 \\
\hline & İl merkezi & 30 & 31.25 \\
\hline & İlçe merkezi & 13 & 13.54 \\
\hline & Kasaba/köy & 4 & 4.17 \\
\hline \multicolumn{2}{|c|}{ Hanede ortalama birey sayısı } & 3.07 & - \\
\hline \multirow{5}{*}{$\begin{array}{l}\text { Hane halkı yaş } \\
\text { dağılımı }\end{array}$} & $0-6$ & 11 & 3.73 \\
\hline & 7-14 & 44 & 14.92 \\
\hline & $15-29$ & 76 & 25.76 \\
\hline & $30-49$ & 104 & 35.25 \\
\hline & 50 ve üzeri & 60 & 20.34 \\
\hline \multirow[t]{3}{*}{ Hanenin aylık geliri (TL) } & $<3000$ & 10 & 10.42 \\
\hline & 3000-3999 & 35 & 36.46 \\
\hline & $\geq 4000$ & 51 & 53.12 \\
\hline
\end{tabular}

\section{ODBÜ'e Yönelik Bilgi Düzeyi}

Hane halkı üyelerine ODBÜ'nin neler oldukları ve bu ürünler konusunda bilgilerinin olup olmadığı sorulduğunda \%40.63'ü biraz bilgim var, \%39.58'i bilgim var, \%19.79'u da bilgim yok yanıtı vermiştir (Çizelge 2). Hane halkı üyeleri ürünlerin genel olarak bilindiğini, fakat ODBÜ olarak tanımlama içinde bilinmediğini ifade etmişlerdir.

Çizelge 2. Hane halklarının ODBÜ konusundaki bilgi düzeyi

Table 2. Knowledge of households about NWFP

\begin{tabular}{lcc}
\hline Bilgi düzeyi & Hane sayısı & $\%$ \\
\hline Bilgisiz & 19 & 19.79 \\
Az bilgili & 39 & 40.63 \\
Bilgili & 38 & 39.58 \\
\hline Toplam & 96 & 100.00 \\
\hline
\end{tabular}

\section{ODBÜ'e Yönelik Bilgi Alma Kaynakları}

Hane halkı üyelerine ODBÜ hakkında bilgi edinme kaynaklarının neler olduğu sorulduğunda en önemli payı \%61.46 ile yakın çevre almıştır. Bunu \%60.41 ile televizyon programları ve $\% 58.33$ ile internet takip etmektedir (Çizelge 3). Hane halklarının ODBÜ nasıl tüketmeye başladıkları konusunda farklı faktörlerin etkili olduğu görülmektedir. Yakın çevre ve geçmişten gelen deneyimler, görsel ve yazılı materyaller bu konuda önemli bir etki yaratmaktadır. Ayrıca kişiler merak ettikleri için de denemek amacıyla bu ürünleri kullanmaya başlamışlar ve bundan sonrada kullanmaya devam etmişlerdir.

Çizelge 3. Hane halklarının ODBÜ ile ilgili bilgi alma kaynakları Table 3. Information resources of the households about NWFP

\begin{tabular}{lcc}
\hline Bilgi kaynakları & Hane sayısı $\left(^{*}\right)$ & $\%$ \\
\hline Yakın çevre & 59 & 61.46 \\
Televizyon programları & 58 & 60.41 \\
Internet & 56 & 58.33 \\
Gazete, dergi vb. & 36 & 37.50 \\
Doktor tavsiyesi & 27 & 28.13 \\
Reklâm & 18 & 18.75 \\
Radyo programları & 12 & 12.50 \\
Satış elemanları & 8 & 8.33 \\
\hline
\end{tabular}

$\left({ }^{*}\right)$ Hane halkı üyeleri birden fazla kaynak belirtmiştir.

\section{ODBÜ Satın Alma Durumu}

Hane halkı üyelerine ODBÜ satın alma sıklığı sorulduğunda \%33.33'ü nadiren, \%33.33'ü bazen, \%29.17'si sık sık, ve \%4.17'si de daima bu ürünleri satın aldıklarını ifade etmişlerdir (Çizelge 4). Sonuç olarak ankete katılan hane halkları arasında ODBÜ yönelik satın alma alışkanlıklarının olduğunu söylemek mümkündür.

\begin{tabular}{|c|c|c|}
\hline Satın alma sıklığı & Hane sayısı & $\%$ \\
\hline Nadiren & 32 & 33.33 \\
\hline Bazen & 32 & 33.33 \\
\hline Sık sık & 28 & 29.17 \\
\hline Daima & 4 & 4.17 \\
\hline Toplam & 96 & 100.00 \\
\hline
\end{tabular}

\section{ODBÜ Satın Alma Sekli}

Hane halkları ODBÜ'i çoğunlukla hem doğadan toplanmış haliyle, hem de işlenmiş paketlenmiş olarak iki şekilde de satın almayı tercih etmektedir (\%56.25). Bazı hanelerin sadece doğadan toplanmış halde (\%14.58) ve sadece işlenip paketlenmiş (\%29.17) olarak satın almayı tercih ettikleri de görülmektedir (Çizelge 5). Ürünlerin işlenmemiş, doğadan toplanarak tüketilmesi durumunda etkisinin insan sağlığı yönünde daha faydalı olduğu inanışı yaygın olması ile birlikte işlenmiş ve paketlenmiş olarak tüketilmesinde en önemli tercih sebebi hijyen olması düşüncesidir. 
Çizelge 5. Hane halklarının ODBÜ satın alma şekli Table 5. NWFP buying method of households

\begin{tabular}{lcc}
\hline ODBÜ satın alma şekli & Hane sayısı & \multicolumn{1}{c}{$\%$} \\
\hline Doğadan toplanmış haliyle & 14 & 14.58 \\
Işlenmiş paketlenmiş olarak & 28 & 29.17 \\
Her iki şekilde & 54 & 56.25 \\
\hline Toplam & 96 & 100.00 \\
\hline
\end{tabular}

\section{ODBÜ Satın Alınan Yerler}

Hane halklarının ODBÜ en fazla satın aldıkları yer \%35.42 ile aktarlardır. Daha sonra \%29.17 ile süpermarket/hipermarketler ve $\% 22.91$ ile semt pazarları en çok tercih edilen satın alma yerleridir (Çizelge 6).

Çizelge 6. Hane halklarının ODBÜ satın aldıkları yerler Table 6. NWFP buying places of households

\begin{tabular}{lcc}
\hline Satın alma yeri & Hane sayısı & $\%$ \\
\hline Aktar & 34 & 35.42 \\
Süpermarket/hipermarket & 28 & 29.17 \\
Semt pazarı & 22 & 22.91 \\
Eczane & 8 & 8.33 \\
Toptancı & 4 & 4.17 \\
\hline Toplam & 96 & 100.00 \\
\hline
\end{tabular}

\section{ODBÜ Fiyatları İle İlgili Görüşler}

Hane halkı üyelerine ODBÜ fiyatları ile ilgili görüşleri sorulmuş ve verdikleri yanıtlar Çizelge 7 'de sunulmuştur. Görüldüğü gibi, \%56.25'i ürün fiyatlarını uygun bulduğunu, \%19.79'u fikri olmadığını, \%16.67'sı yüksek ve \%7.29'u düşük bulduğunu ifade etmiştir.

Çizelge 7. Hane halklarının ODBÜ fiyatları hakkındaki görüşleri Table 7. The opinion of the households about prices of NWFP

\begin{tabular}{lcc}
\hline Satın alma sıklığı & Hane sayısı & $\%$ \\
\hline Fikrim yok & 19 & 19.79 \\
Düşük & 7 & 7.29 \\
Uygun & 54 & 56.25 \\
Yüksek & 16 & 16.67 \\
\hline Toplam & 96 & 100.00 \\
\hline
\end{tabular}

\section{Tüketimi Tercih Edilen ODBÜ}

Hane halkı tarafından en çok tercih edilen ürün nanedir. Bu ürünü ıhlamur, kekik, adaçayı, salep, çörek otu ve ısırgan otu takip etmektedir En az satın alınan ürünler ise; at kuyruğu, laden, ökseotu ve civanperçemidir (Çizelge 8).

\section{ODBÜ Tüketim Amaçları}

Hane halklarının ODBÜ tüketim amaçları Çizelge 9 'da sunulmuştur. Bu ürünlerin en fazla genel sağlık amaçlı kullanıldığı görülmektedir. Bunun yanı sıra tedavi ve keyif amaçlı kullanımı tercih edenler de bulunmaktadır. Genellikle tüketicilerin doğal bitkilerin daha çok koruyucu ve bağışıklık sistemini kuvvetlendirici özelliklerinden faydalanmayı amaçladıkları görülmektedir. Son yıllarda insan sağlığını ve yaşam kalitesini artırmaya yönelik bilinçlenme ve bunun beraberinde getirdiği önleyici ve koruyucu tedaviye yönelme ODBÜ'nin daha çok tercih edilmesindeki amaçlar arasındadır.

Çizelge 8. Hane halklarının tercih ettikleri ODBÜ Table 8. NWFP preferred by households

\begin{tabular}{lcccc}
\hline \multirow{2}{*}{ ODBÜ } & \multicolumn{2}{c}{ Satın alan } & \multicolumn{2}{c}{ Satın almayan } \\
\cline { 2 - 5 } & Hane & $\%$ & $\begin{array}{c}\text { Hane } \\
\text { sayısı }\end{array}$ & $\%$ \\
\hline Kantaron & 39 & 40.62 & 57 & 59.38 \\
Kekik & 80 & 83.33 & 16 & 16.67 \\
Adaçayı & 68 & 70.83 & 28 & 29.17 \\
Ihlamur & 83 & 86.46 & 13 & 13.54 \\
Nane & 89 & 92.71 & 7 & 7.29 \\
Defne & 42 & 43.75 & 54 & 56.25 \\
Ebegümeci & 21 & 21.87 & 75 & 78.13 \\
Kuşburnu & 55 & 57.29 & 41 & 42.71 \\
Anason & 15 & 15.63 & 81 & 84.37 \\
Rezene & 30 & 31.25 & 66 & 68.75 \\
Papatya & 33 & 34.38 & 63 & 65.62 \\
Salep & 61 & 63.54 & 35 & 36.46 \\
Biberiye & 24 & 25.00 & 72 & 75.00 \\
Oğul Otu & 21 & 21.88 & 75 & 78.12 \\
Civan Perçemi & 7 & 7.29 & 89 & 92.71 \\
Ökse Otu & 6 & 6.25 & 90 & 93.75 \\
Ayva Yaprağı & 16 & 16.67 & 80 & 83.33 \\
Çörek Otu & 62 & 64.58 & 34 & 35.42 \\
Keten Tohumu & 41 & 42.71 & 55 & 57.29 \\
Karabaş Otu & 16 & 16.67 & 80 & 83.33 \\
At Kuyruğu & 3 & 3.13 & 93 & 96.87 \\
Isırgan Otu & 37 & 38.54 & 59 & 61.46 \\
Fesleğen & 29 & 30.21 & 67 & 69.79 \\
Laden & 5 & 5.21 & 91 & 94.79 \\
Sumak & 54 & 56.25 & 42 & 43.75 \\
\hline & & & & \\
\hline
\end{tabular}

Çizelge 9. Hane halklarının ODBÜ tüketim amaçları Table 9. NWFP consumption purposes of households

\begin{tabular}{lcr}
\hline Tüketim amaçları & Hane sayısı & \multicolumn{1}{c}{$\%$} \\
\hline Genel sağlık & 24 & 25.00 \\
Tedavi & 8 & 8.33 \\
Keyif & 20 & 20.83 \\
Genel sağlık ve tedavi & 7 & 7.29 \\
Genel sağlık ve keyif & 21 & 21.88 \\
Genel sağlık, tedavi ve keyif & 14 & 14.59 \\
Kozmetik & 2 & 2.08 \\
\hline Toplam & 96 & 100.00 \\
\hline
\end{tabular}

\section{ODBÜ Tüketim Şekilleri}

Hane halklarının ODBÜ tüketim şekilleri ile ilgili sonuçlar Çizelge 10 'da verilmiştir. Görüldüğü gibi hane hakları bu ürünleri en fazla \%37.50 ile demleme ve gıdalara karıştırarak tüketmektedir. Bunun yanı sıra \%29.17 ile sadece haşlama ve demleme şeklindeki tüketimi tercih eden hane halkları da bulunmaktadır. 
Çizelge 10. Hane halklarının ODBÜ tüketim şekilleri Table 10. NWFP consumption methods of households

\begin{tabular}{lcc}
\hline ODBÜ tüketme şekli & Hane sayısı & $\%$ \\
\hline Demleme ve gıdalara karıştırma & 36 & 37.50 \\
Haşlayarak demleme & 28 & 29.17 \\
Gıdalara karıştırma & 15 & 15.63 \\
Demleme, gıdalara karıştırma ve yağ & 11 & 11.46 \\
olarak & 4 & 4.16 \\
Merhem olarak & 2 & 2.08 \\
Yağ olarak & 96 & 100.00 \\
\hline Toplam & &
\end{tabular}

\section{ODBÜ Tüketmede Çeşitli Kriterlere Verilen Önem Düzeyinin Analizi}

Araştırmada hane halkının ODBÜ tüketmede öncelik verdiği kriterleri ortaya koymak amacıyla Bulanık Eşli Karşılaştırma (BEK) yönteminden yararlanılmıştır. Yönteme göre hane halkı üyeleri iki kriteri karşılaştırmaktadır. Araştırmada hane halkı üyesinden ODBÜ tüketmede aşağıdaki kriterler arasında eşli karşılaştırmalar yapması istenmiştir.

1. Fiyat

2. Marka

3. Ambalaj

4. Güvenilir ürün

5. Sağlık ve besin değeri

BEK yöntemi sonuçlarına ilişkin tamamlayıcı istatistikler Çizelge $11^{\prime}$ 'de verilmiştir. Elde edilen ağırlıklara göre tüketimde etkili kriterler büyükten küçüğe sıralanmıştır. Hane halkı üyelerinin tüketimde en çok önem verdikleri kriter fiyat olarak saptanmıştır. Ambalaj ikinci, marka ise üçüncü sırada gelmektedir. Önem verilen en son kriter ise güvenilir ürün olmasıdır.

Çizelge 11.ODBÜ tüketmede kriter tercihleri

Table 11. Criterion preferences for NWFP consumption

\begin{tabular}{lcccc}
\hline Kriterler & Ortalama & $\begin{array}{c}\text { Standart } \\
\text { sapma }\end{array}$ & Minimum & Maksimum \\
\hline Fiyat & 0.588 & 0.154 & 0.165 & 0.900 \\
Ambalaj & 0.549 & 0.129 & 0.100 & 0.900 \\
Marka & 0.509 & 0.112 & 0.286 & 0.800 \\
$\begin{array}{l}\text { Sağlık ve besin } \\
\text { değeri }\end{array}$ & 0.349 & 0.126 & 0.100 & 0.582 \\
Güvenilir ürün & 0.344 & 0.129 & 0.100 & 0.629 \\
\hline
\end{tabular}

Friedman testi $p<0.01$ için anlamlıdır. Kendall's W: 0.375

Friedman testi sonuçlarına göre tercihler arasında istatistiksel olarak anlamlı bir fark vardır. Bu sonuca göre, tüketim kararıyla ilgili bazı kriterlerin, diğerlerinin üzerinde tercih edildiğini söylemek mümkündür. Kendall's W değeri 0.375 olarak belirlenmiştir.

\section{TARTIŞMA ve SONUÇ}

Doğal olana dönüş, katkısız ürünleri tüketme talebi ile birlikte kendi doğal ortamında yetişen ODBÜ tüketimi konusunda gerek kentsel kesimde ve gerekse kırsal kesimde yaşayanların, tüketim tercihleri dikkate alınarak ürün çeşitliliğinin belirlenmesi büyük önem taşımaktadır. Tüketici tercihlerini dikkate alan pazarlama yaklaşımı ile ürünlerin hangilerine ne miktarda ve hangi formlarda talep olduğunun belirlenmesine yönelik üretimin yapılması gerekmektedir. Üretilecek ürün çeşitlerinin ve tahmini üretim miktarlarının planlanması ile sektörde çalışan firmalar elde edilen bu bulgular ışığında pazar kitlelerini belirleyebilecektir. Tüketicilerin tercih ettiği çeşit, miktar ve şekilde ürün üretimi ile tüketici kitlesinin doğru belirlenmesi üretimden pazarlamaya kadar olan sürecin etkin çalışmasını ve sürdürülebilirliğini sağlayabilecektir.

Gerek kendi doğal ortamlarına zarar verilmeden usulüne uygun olarak toplanan ODBÜ miktarı ve gerekse tarla koşullarında üretilecek ürün miktarları ürünün arz-talep durumuna göre belirlenmelidir. Kültüre alınmış bitkilerin yetiştiriciliği üreticilere benimsettirilmeli, kooperatif bazında örgütlenme ile yetiştirilen ürünler işlenerek, ambalajlı olarak tüketicilere pazarlanmalıdır. Bu durumda sektörün intiyacına cevap verecek kalite ve standartları belirlenmiş ürün çeşitliğinin devamlılığı sağlanacaktır.

Ürünleri en çok satın almada tercih edilen yer aktarlardır. Pazarlamada etkin rol oynayan aktarların kimlerden oluşabileceği ve bu mesleğin ne şekilde yapılması gerektiği yasal olarak belirlenmelidir.

Diğer taraftan, görsel ve yazılı iletişim araçları ile ürünlerin doğru ve yerinde kullanımı konusunda, tüketicilere tanıtılması, farkındalık oluşturulması ve özellikleri konularında bilgilendirilmesi büyük yarar sağlayacaktır.

ODBÜ işleyen firmaların AR-GE faaliyetlerini arttırarak ve pazarın istediği ürünlerin çeşitliliğini yaygınlaştırarak modern işleme yöntemleri ile yeni ürünler sunmaları teşvik edilmelidir. Bu sektörde çalışan üretici, toplayıcı, sanayici ve diğer tüm konu ile ilgili kesimler arasında koordinasyon sağlanarak yapılan araştırma çalışmalarının sonuçlarının pratiğe aktarılması için eğitim ve yayım sistemi geliştirilmelidir. 


\section{KAYNAKLAR}

Arslan, N., H. Baydar, S. Kızıl, Ü. Karık, N. Sekercioğlu ve A. Gümüş̧̧ü. 2015. Tibbi ve aromatik bitkiler üretiminde değişimler ve yeni arayışlar, Türkiye Ziraat Mühendisliği VIII.Teknik Kongresi, 12-16 Ocak 2015, Ankara, s.483-507.

Artukoğlu, M. M., A. Uzmay and A.Olgun. 2002. An evaluation of medicinal and aromatic plant trade in the World, in the EU and in Turkey, Agro-Food Industry Hi-Tech, 13(6):19-22.

Artukoğlu, M., M. ve A. Uzmay. 2003. Tibbi ve Aromatik Bitkiler İç ve Dış Ticareti Üzerine Bir Araştırma, İzmir Ticaret Odası Yayınları, İzmir, $42 \mathrm{s.}$

Bayram, E., E. Kırıcı, S. Tansi, G. Yılmaz, O. Arabacı, S. Kızıl ve İ. Telci. 2010. Tibbi ve aromatik bitkiler üretiminin arttırılması olanakları, Ziraat Mühendisliği VII. Teknik Kongresi, 11-15 Ocak 2010, Ankara, s. 437-457.

Bektaş, Z., B. Miran, Ö. Uysal, C. Günden ve M. Cankurt. 2009. İzmir ilinde tüketicilerin dondurulmuş gida ürünlerine yönelik satın alma davranışları üzerine bir araştırma, E.Ü. Bilimsel Araştırma Projeleri, Proje No:2006-ZRF-043, İzmir, 307 s.

Bilgin, F. 1996. Orman tali ürünlerinden çamfıstı̆̆ının (fıstıkçamı) Izmir-Bergama ilçesi Kozak yöresi tarım işletmelerinde üretim, değerlendirme ve pazarlamasının iyileştirilmesi üzerine bir araştırma, Yüksek Lisans Tezi, Ege Üniversitesi Fen Bilimleri Enstitüsü, İzmir, $105 \mathrm{~s}$.

Dicle, M. 2010. İzmir ili Bornova ilçesinde tıbbi bitkilere ilişkin tüketici davranışlarının belirlenmesi üzerine bir araştırma, Yüksek Lisans Tezi, Ege Üniversitesi Fen Bilimleri Enstitüsü, İzmir, $89 \mathrm{~s}$.

Faydaoğlu, E. ve M.S. Sürücüoğlu. 2011. Geçmişten günümüze tıbbi ve aromatik bitkilerin kullanılması ve ekonomik önemi, Kastamonu Üniversitesi Orman Fakültesi Dergisi, 11(1):52-67.

Günden, C. ve B. Miran. 2007. Bulanık eşli karşılaştırma yöntemiyle çiftçilerin amaç hiyerarşisinin belirlenmesi üzerine araştırma, Akdeniz Üniversitesi Ziraat Fakültesi Dergisi, 20(2):183-191

Günden, C. and T. Thomas. 2012. Assessing consumer attitudes towards fresh fruit and vegetable attributes, Journal of Food Agriculture and Environment, 10(2):85-88.

Karayılmazlar, S. ve H. Yazıcı. 2002. Türkiye'nin odun dışı orman ürünleri içerisinde Batı Karadeniz bölgesinde yetișen defne'nin ekonomik değeri ve önemi, II. Ulusal Karadeniz Ormancilık Kongresi, 15-18 Mayıs 2002, Trabzon, s.289-295.

Klir, G.J. and B. Yuan. 1995. Fuzzy Sets and Fuzzy Logic: Theory and Application. Prentice Hall, New Jersey, 574 p.
Korkmaz M. ve H. Fakir. 2009. Odun dışı bitkisel orman ürünlerine ilişkin nihai tüketici özelliklerinin belirlenmesi, Süleyman Demirel Üniversitesi Orman Fakültesi Dergisi, 2(1):10-20.

Newbold, P. 1995. Statistics for Business and Economics, PrenticeHall, New Jersey, p.887.

Özden, A. 2016. Measuring environmental efficiency in the EU agricultural sector: considering desirable and undesirable outputs, Fresenius Environmental Bulletin, 25 (1): 240-248.

Özden, A. and R. Dios-Palomares. 2015. Environmental, quality and technical efficiency in olive oil industry. A metafrontier comparison between Turkey and Spain, Fresenius Environmental Bulletin, 24 (12): 4353-4363.

Özgüven, M., S. Sekin, B. Gürbüz, N. Sekeroğlu, F. Ayanoğlu ve S. Erken. 2005. Tütün, tıbbi ve aromatik bitkiler üretimi ve ticareti, Türkiye Ziraat Mühendisleri VI. Teknik Kongresi, 3-7 Ocak 2005, Ankara, s.481-501.

Özkan, Z.C., N. Merev, S.Terzioğlu, A.Ö.Üçler, C.Gümüş ve D. Toksoy. 2002. Gümüşhane yöresi doğal tıbbi bitkilerinin tanınması, yetiştirilmesi ve değerlendirilmesi, Proje Sonuç Raporu, Gümüşhane Valiliği, Gümüşhane, s.102.

Özuğurlu, E. ve M. Düzgün. 2000. Policies to promote sustainable operations and utilization of non-wood forest products in Turkey, Proceedings of Seminar on Harvesting of Non-Wood Forest Products, 2-8 October 2000, Menemen-İzmir, Turkey, p. 113-122.

Pedrycz, W. and F. Gomide. 1998. An Introduction to Fuzzy Sets. The MIT Press, Massachusetts, $465 \mathrm{p}$.

Prasad, R. 1999. Joint forest management in india and the impact of state control overnon-wood forest products, Unasylva, 198:58-62.

Tanaka, K. 1997. An Introduction to Fuzzy Logic for Practical Applications. Springer - Verlag, New York, 138 p.

Türker, M. F., A. Öztürk, M. Pak ve E. Tiryaki. 2001. Türkiye ormancılığında odun dışı orman ürünleri işletmeciliğinde karşılaşılan sorunlar ve çözüm önerileri, I. Ulusal Ormancıllk Kongresi, 19-20 Mart 2001, Ankara, s.306-316.

Türker, M.F., A. Öztürk ve E. Tiryaki. 2002. Ülkemiz ormancilı sektöründe odun dışı orman ürünleri kapsamında değerlendirilen odun dışı bitkisel ürünlerin işletmeciliği, II. Ulusal Karadeniz Ormancilı Kongresi, 15-18 Mayıs 2002, Trabzon, s.270-279.

Türker, M.F., A. Öztürk, M. Pak ve İ. Durusoy. 2006. Odun Dışı Organik Orman Ürünleri ve Yönetimi, Sürdürülebilir Rekabet Avantajı Elde Etmede Organik Tarım Sektörü: Sektörel Stratejiler ve Uygulamalar, Birinci Baskı, s.499-543. 